\title{
The Effect of Progesterone Administration on the Expression of Metastasis Tumor Antigens (MTA1 and MTA3) in Placentas of Normal and Dexamethasone-Treated Rats
}

\section{Mariam Alawadhia}

Kuwait University Faculty of Medicine

\section{Farah Al Shammari}

Kuwait University Faculty of Medicine

\section{Fatemah Mulla Ali}

Kuwait University Faculty of Medicine

Rama Almatar

Kuwait University Faculty of Medicine

Ayat Al-Duwaikhi

Kuwait University Faculty of Medicine

Maie D. Al-Bader ( $\square$ maie.albader@ku.edu.kw )

Kuwait University Faculty of Medicine https://orcid.org/0000-0002-1235-5437

\section{Research Article}

Keywords: Pregnancy, placental efficiency, Fetal growth restriction, Progesterone, Metastasis tumor antigens

Posted Date: June 17th, 2021

DOI: https://doi.org/10.21203/rs.3.rs-426175/v1

License: (c) (i) This work is licensed under a Creative Commons Attribution 4.0 International License. Read Full License

Version of Record: A version of this preprint was published at Molecular Biology Reports on January 17th, 2022. See the published version at https://doi.org/10.1007/s11033-021-07005-5. 


\section{Abstract}

\section{Background}

Dexamethasone (DEX) induces intrauterine growth restriction (IUGR) in pregnant rats. IUGR can occur due to apoptosis of trophoblasts, which is believed to be inhibited by progesterone (P4). A group of genes called MTAs play a role in proliferation and apoptosis. MTA1 upregulates trophoblasts proliferation and differentiation, while MTA3 downregulates proliferation and induces apoptosis. Hence, we hypothesized that during IUGR, placental MTA1 decreases and MTA3 increases and this is reversed by P4 treatment.

Methods

Pregnant Sprague-Dawley rats were divided into 4 groups based on daily intraperitoneal injections: control (C, saline), DEX (DEX, $0.2 \mathrm{mg} / \mathrm{kg} /$ day), DEX and P4 (DEX + P4, DEX: $0.2 \mathrm{mg} / \mathrm{kg} / \mathrm{day}, \mathrm{P} 4: 5$ $\mathrm{mg} / \mathrm{kg} /$ day) and $\mathrm{P} 4$-treated (P4, $5 \mathrm{mg} / \mathrm{kg} /$ day) groups. Injections were started on $15 \mathrm{dg}$ until the day of dissection (19 or $21 \mathrm{dg}$ ). Gene and protein expressions of MTA1 and MTA3 were studied in the labyrinth (LZ) and basal (BZ) zones using real-time PCR and Western blotting, respectively.

Results

DEX treatment induced $18 \%$ reduction in fetal body weight $(p<0.001)$ and $30 \%$ reduction in placental weight $(p<0.01)$. Maternal P4 level was also significantly lower in DEX treated groups $(p<0.05)$. MTA1 expression was decreased in the LZ (gene, $p<0.001$ ) and BZ (protein $p<0.01$ ), while MTA3 protein expression was upregulated in the LZ with DEX treatment $(p<0.001)$. These changes were reversed with P4 treatment.

Conclusion

The findings of the present study indicate that DEX induces IUGR through changing the expression of placental MTA1 and MTA3 antigens and P4 improved pregnancy outcome by preventing the changes in MTAs expression.

\section{Introduction}

Intrauterine growth restriction (IUGR) is used to describe fetal outcomes that fail to reach the full growth potential. Several factors can lead to IUGR, most commonly antenatal exposure to glucocorticoids (GC). Intrauterine growth restriction has been correlated with lower levels of maternal progesterone (P4) levels $[1,2]$.

Progesterone is known for its importance in the initiation and maintenance of pregnancy [3]. During early pregnancy P4 plays a vital role in blastocyst implantation [4] and it has anti-abortive effect through 
suppressing the immune system $[5,6]$. Progesterone is known for its role in proliferation and differentiation through activation of Wnt signalling pathway $[7,8]$. Progesterone also induces placental angiogenesis through modulating vascular endothelial growth factor [9], and increasing the blood flow through the release of nitric oxide [10]. In addition, it is known for its anti-apoptotic effect through upregulating the expression of anti-apoptotic regulatory protein BCL-2 and modulating Wnt signalling pathway $[7,11-13]$.

Lower levels of maternal P4 were correlated with IUGR [1, 2], which could be the underlying cause behind less proliferation and angiogenesis and increase apoptosis seen in IUGR placentas [14-17]. Due to the vital role of P4 during pregnancy, several studies evaluated the effect of exogenous P4 administration on pregnancy outcomes. During early pregnancy, P4 treatment in spontaneous preterm delivery improved pregnancy rate by $45 \%$ as well as the gestational duration [18-20]. Antenatal P4 treatment in complicated pregnancies, improved postpartum maternal and fetal general wellbeing including fetal weight, less administration to intensive care unit and fetal morbidity [19-22]. The exact mechanism of P4 modulatory effect is unknown. However, one of the mechanisms is believed to be through modulating the apoptotic pathway in the placenta [23].

Metastasis tumor antigens (MTA) represent a small family of gene products encoded by three distinct genes in humans (MTA1, MTA2, MTA3) [24]. MTAs co-regulate essential components in proliferation, differentiation and apoptosis pathways MTA1 exhibits up-regulation of beta-catenin and cyclin D1, which are indicators of activated Wnt pathway, thus cell proliferation and differentiation [25-27]. On the other hand, MTA3 represses the activity of beta-catenin and thus Wnt pathway, inhibiting cell proliferation and inducing apoptosis $[27,28]$. In IUGR placentas, MTA3 was found to be upregulated along with downregulation of beta-catenin, indicating a lower level of trophoblast proliferation and increased placental cell apoptosis in IUGR [16].

Progesterone is an important hormone during pregnancy. Recent evidence showed that pregnancies complicated with IUGR are related to lower levels of maternal P4. In addition, these pregnancies showed decreased placental trophoblast proliferation and increased placental apoptosis manifested by alteration in the level of placental MTA1 and MTA3 expressions. Antenatal P4 proved to show modulatory effect on fetal body weight and wellbeing after birth in IUGR pregnancies. So in this study we aim to evaluate the modulatory effect of P4 on DEX-induced IUGR outcomes and on gene and protein expression of MTA1 and MTA3 in the placental labyrinth and basal zones (LZ and BZ) of IUGR placentas.

\section{Methods}

\section{Animals and Experimental Design}

Sprague-Dawley (SD) rats (8-12 weeks old; Animal Resource Center, Faculty of Medicine at Kuwait University; treated according to National Institute of Health $(\mathrm{NIH})$ and Animal Research: Reporting In Vivo Experiment (ARRIVE) guidelines and approved by Kuwait University Health Sciences Center Animal 
Research Ethics Committee). Experimental rats had free access to water and food and maintained on 12 hrs light/dark cycles, at $22^{\circ} \mathrm{C}$. Rats were mated overnight, the morning at which sperms were detected in the vaginal smear was considered as 0 day of gestation (dg); rats were then caged individually. At $15 \mathrm{dg}$ the rats were divided randomly into 4 treatment groups ( $n=6 /$ group) based on daily intraperitoneal (i.p) injections of: saline (control group, $\mathrm{C}$ ), Dexamethasone ( $0.2 \mathrm{mg} / \mathrm{kg} /$ day, DEX group), Dexamethasone (0.2 $\mathrm{mg} / \mathrm{kg} /$ day) and Progesterone (5 mg/Kg/day, DEX + P4 group) and progesterone ( $5 \mathrm{mg} / \mathrm{Kg} / \mathrm{day}, \mathrm{P} 4$ group). Treatment dose and duration of DEX were modified from Shoener et al and Alqaryyan [16, 29], whereas P4 treatment was adopted from Hashimoto [30]. All treatments started from $15 \mathrm{dg}$ until the day of sacrifice (19 dg and $21 \mathrm{dg}$ ). The days of sacrifice were chosen based on previous reports regarding placental and fetal growth potentials; where the placenta reaches its maximum growth at $19 \mathrm{dg}$, and the fetus reaches its maximum growth by $21 \mathrm{dg}[16,31]$. None of the rats had signs of labour at the time of termination of the experiment. No treatment was given on the day of sacrifice to avoid the acute effect of the treatment. Figure 1 shows the experimental design.

\section{Tissue Collection}

On days 19 and 21 gestation, pregnant rats were exposed to $\mathrm{CO}_{2}(1 \mathrm{~min})$ followed by cervical dislocation. The chest was opened and maternal blood was taken from the right ventricle of the heart in serum collecting tubes with clot activator gel. The tubes were kept on ice for $30 \mathrm{~min}$, followed by centrifugation at $3000 \mathrm{x} \mathrm{g}$ for $10 \mathrm{~min}$. The supernatant was stored at $-80^{\circ} \mathrm{C}$. A longitudinal abdominal incision was done and the uterus containing the fetuses was removed. Both the fetuses and the placentas (LZ and BZ) were separated on ice and weighed. All fetuses were alive at the time of dissection. The LZ and BZ of placentas of 1 dam were pooled and considered as $n=1$. Pregnancies with pups less than 8 or larger than 13 were excluded, since there was an inverse relationship between litter number and fetal body weight independent of any other factor [32].For RNA analysis plasental zones were snap frozen in liquid nitrogen for 5 minutes and stored at $-80^{\circ} \mathrm{C}$; and for protein analysis, the cryoprotective agent dimethylsulfoxide (10\% v/v DMSO, Sigma Aldrich Co, USA) was added to samples before freezing at $-80^{\circ} \mathrm{C}$.

\section{Hormone Measurement}

Rat progesterone Enzyme-Linked Immunosorbent Assay (ELISA) kit (Cat\# R0775, Elabscience, Texas, United Sates) with sensitivity of $0.2 \mathrm{ng} / \mathrm{ml}$ was used to estimate the level of maternal serum P4. The assay procedure was performed according to the manufacturer's instructions.

\section{Gene Studies using Real-Time PCR (ReT-PCR)}

Gene expression of MTA1 and MTA3 in placental LZ and BZ were studied using ReT-PCR as described previously [16, 33]. RNA extraction was performed using the TRIzol method (Invitrogen, Massachusetts, USA). RNA purity and quantity were measured using Epoch microplate spectrophotometry (Epoch Tak 3 plate, Biotech Instruments, Vermont, USA) at wavelengths of $260 \mathrm{~nm}$ and $280 \mathrm{~nm}$. Samples with A260/A280 ratio > 1.7 were considered pure and used for further analysis. The integrity of samples were checked by agarose gel electrophoresis ( $1 \% \mathrm{wt} / \mathrm{vol}$.) stained with ethidium bromide and visualized under 
UV transilluminator light using Gene Genius Bio Imaging System (Syngene, Cambridge, UK). Only samples with intact RNA were used for further analysis. Genomic DNA was removed from samples (DNase-treated), followed by reverse transcription (reagents purchased either from Invitrogen Incorporation or Applied Biosystems).

TaqMan assays (Applied Biosystems, California, USA) were used for the housekeeping (Rat actin, assay ID. Rn00667869_m1) and target genes: MTA1 (Assay ID. Rn00574899_m1) MTA3 (Assay ID.

Rn0001472640_m1). The PCR reaction was conducted as follows: 2 min at $50^{\circ} \mathrm{C}(1 \mathrm{cycle}), 10 \mathrm{~min}$ at $95^{\circ} \mathrm{C}$ (1cycle), alternate 15 secs at $95^{\circ} \mathrm{C}(60$ cycles $)$ and $1 \mathrm{~min}$ at $60^{\circ} \mathrm{C}$.

The relative quantitative expression of target gene was done as described in our earlier study [34] based on Livak method for relative gene expression [35]. Cycle threshold (Ct) was used to calculate the relative quantification of the target gene expression compared to the calibrator (19 dg control). The $\mathrm{Ct}$ value of the housekeeping gene (actin) was subtracted from the target gene and expressed as $\Delta \mathrm{Ct}$. The $\Delta \Delta \mathrm{Ct}$ was calculated by subtracting the $\Delta$ Ct value from that of the calibrator ( $19 \mathrm{dg}$ control). The normalized gene expression was then determined by using $2^{-} \Delta \Delta \mathrm{Ct}$.

\section{Western Blotting Analysis}

Protein expression of MTA1 and MTA3 in both placental LZ and BZ was done using Western blotting followed by immunodetection. After washing each of the placental zones twice with ice-cold saline, the samples were homogenized in radioimmunoprecipitation assay (RIPA) buffer (50 mM pH7.4 Tris, 150 $\mathrm{mM} \mathrm{NaCl}, 1 \% \mathrm{NP}-40,5 \mathrm{mM}$ EDTA, 0.5\% Na-deoxycolate, 0.1\% SDS, 2 mM benzamidine, phyenylmethylsulfonyl fluoride (PMSF) containing a tablet of EDTA-free protease inhibitor. Samples were kept on ice for $1 \mathrm{hr}$ then centrifuged (47000 $\mathrm{g}$ for $25 \mathrm{~min}$ ). The supernatant was collected for protein estimation that was done using Epoch microplate spectrophotometry. Polyacrylamide precast gels (4$20 \%$ mini-protean TGX precast protein gels, Biorad Laboratories, USA) were used for electrophoresis. Samples were prepared by adding NuPage LDS sample buffer (4X) and NuPage sample reducing agent (10X) (Invitrogen, USA) to $70 \mu \mathrm{g}$ samples before loading. Protein size was determined using rainbow protein marker (ECL rainbow marker-high range, GE Healthcare Lifescience). HEPES running buffer (10X) was prepared as indicated by the manufacturer (Tris 121g, HEPES 238g, SDS $10 \mathrm{~g}$ in $1 \mathrm{~L} \mathrm{ddH}_{2} \mathrm{O}$ ). For gel electrophoresis, a constant voltage of $250 \mathrm{~V}$ with a current of $60 \mathrm{~mA} / \mathrm{gel}$ was applied.

Proteins were then transferred to Polyvinylidene fluoride (PVDF) membrane using transfer buffer (10X) as indicated by the manufacturer $(25 \mathrm{mM}$ Tris- $\mathrm{HCl}, 150 \mathrm{mM}$ glycine, $\mathrm{pH}$ 8.3). After the transfer, membranes were stained with ponceau red stain $(0.1 \% \mathrm{w} / \mathrm{v}$ ponceau $\mathrm{S}, 5 \% \mathrm{v} / \mathrm{v}$ acetic acid) and bands to confirm band transfer. Membranes were then washed out with distilled water several times until the colour disappeared. Membranes then were blocked using $10 \%$ non-fat dry milk in TBS-T ( $20 \mathrm{mM}$ Tris, $137 \mathrm{mM} \mathrm{NaCl}, \mathrm{pH} 7.6$, $0.1 \% \mathrm{v} / \mathrm{v}$ Tween) for $1 \mathrm{hr}$ at room temperature. After washing the membrane with TBS-T (rinsed twice followed by $20 \mathrm{ml}$ wash for $10 \mathrm{~min}$ ); membranes were incubated with diluted (5\% non-fat dry milk in TBST) primary antibodies overnight at $4^{\circ} \mathrm{C}$ (Supplementary Table 1). The next morning, after washing the membranes with TBS-T (rinsed twice followed by 3 washes of $20 \mathrm{ml} / \mathrm{wsh}, 10 \mathrm{~min}$ each), appropriate 
secondary antibodies were diluted in milk and incubated for $2 \mathrm{hrs}$ at room temperature (Supplementary Table 1). Bands were detected using Western blotting luminol reagent kit (Santa Cruz Biotechnology, USA). Then membranes were placed in a cassette and exposed to Kodak films (Sigma Aldrich, catalogue no. z358495). Membranes were then washed with TBS-T and incubated overnight with actin. Next morning the membrane was washed and incubated with appropriate secondary antibody for actin (Supplementary Table 1). Gene Genius Bio Imaging System was used to measure the optical density (OD) of each sample band and normalized to actin and the positive control ODs.

\section{Statistical Analysis}

Statistical differences between groups were evaluated using package for statistical analysis (SPSS). The homogeneity of variances were evaluated followed by evaluating the significance using two way analysis of variance (ANOVA). Least significant difference (LSD) post hoc analysis was used if the variance was homogeneous, whereas Games-Howell post hoc analysis was used when variances of homogeneity was absent. A p value of $<0.05$ was considered significant. All data were expressed as mean \pm standard error of the mean (SEM). All figures were created using Microsoft Excel Software.

\section{Results}

\section{Dexamethasone Induces IUGR and Decreases Maternal Progesterone Level}

Fetal body weight increased significantly with gestation from 19 to $21 \mathrm{dg}$ in all experimental groups ( $\mathrm{p}$ 0.001 ; Fig. 2.a). On 21 dg, treatment with DEX resulted in a reduction (18\%) in fetal body weights compared to the $C$ and $P 4$ groups ( $p<0.001$ and $p<0.05$, respectively; Fig. 2.a), indicating a clear IUGR caused by DEX treatment. Co-administration of DEX and P4 prevented the reduction in fetal body weight seen with DEX treatment.

At $19 \mathrm{dg}$, the maternal serum levels of P4 in the DEX + P4 group was significantly higher compared to all other groups $(p<0.01-p<0.001$; Fig. 3). Towards the end of pregnancy, by $21 \mathrm{dg}$, maternal serum levels of P4 dropped significantly in all the groups compared to their corresponding groups at $19 \mathrm{dg}(p<0.05-p$ $<0.001$, Fig. 2.b). At $21 \mathrm{dg}$, DEX treatment resulted in $36 \%$ reduction in maternal P4 level compared to the C group ( $p<0.05$, Fig. 2.b).

\section{Dexamethasone Restricts Placental Growth}

Placental weight did not change from 19 to $21 \mathrm{dg}$. At $21 \mathrm{dg}$, DEX-induced IUGR resulted in lower weight of whole placentas, LZ and BZ compared to C group ( $30 \%, 31 \%$ and $38 \%$ respectively, $p<0.05$; Table 1 ). Progesterone co-treatment with DEX prevented the reduction in whole placental weight as well as in the weight of the basal zone $(p<0.05$, Table 1$)$ compared to DEX-treated placentas. 
Placental efficiency evaluates the placental function in fetal formation, measured as fetal weight divided by placental weight. Placental efficiency increased significantly with the progression of gestation in all groups compared to $19 \mathrm{dg}(\mathrm{p}<0.001$, Table 1). At $21 \mathrm{dg}$, DEX treatment resulted in increased placental efficiency compared to $C$ and $P 4$ groups $(p<0.05$, Table 1$)$. The efficiency was improved furthermore when DEX was co-treated with progesterone at $21 \mathrm{dg}(\mathrm{p}<0.001$, Table 1$)$.

\section{The Effect of Different Treatments on Placental MTA1 Gene and Protein Expression}

MTA1 gene expression in the LZ was significantly reduced $(p<0.001)$ in all experimental groups compared to $C$ group at $19 \mathrm{dg}$ ( $p<0.001$; Fig. 3.a). With progression of pregnancy, at $21 \mathrm{dg}$, all groups showed a significant increase in the level of MTA1 gene expression compared to their corresponding groups at $19 \mathrm{dg}(p<0.05-p<0.001$; Fig. 3.a). A single $~ 80 \mathrm{kDa}$ band was detected for MTA1 and unlike the gene expression, the protein expression in the LZ showed a significant reduction in MTA1 level at 21 $\mathrm{dg}$ in all groups compared to their corresponding groups at $19 \mathrm{dg}(p<0.05-p<0.01$; Fig. 3.b). No significant differences in protein levels were detected among the groups in this zone at any of the gestational ages.

MTA1 gene expression in the BZ was significantly higher in P4 treated group at $19 \mathrm{dg}$ compared to all other groups at this age ( $p<0.01$, Fig. 3.c). The significant increase in MTA1 gene expression in P4 disappeared at $21 \mathrm{dg}(\mathrm{p}<0.01$, Supplementary Fig. 5$)$ due to significant reduction in gene expressoion in P4 group compared to $19 \mathrm{dg}(\mathrm{p}<0.001$, Supplementary Fig. 5). At the protein level, both DEX treated groups (DEX and DEX + P4) showed significant lower expression of MTA1 compared to $C$ and P4 groups at $19 \mathrm{dg}(p<0.001$; Fig. 3.d). The effect of DEX on MTA1 expression in the basal zone disappeared with progression of gestation ( $21 \mathrm{dg}$ ) since the level of protein in $\mathrm{C}$ and $\mathrm{P} 4$ groups decreased significantly at $21 \mathrm{dg}$ compared to $19 \mathrm{dg}(\mathrm{p}<0.001$; Fig. 3.d) .

MTA3 gene expression did not show any significant difference between groups at any gestational age (Fig. 4.a). At the protein level, a single $60 \mathrm{kDa}$ band was detected for MTA3 in both placental zones. In the LZ, DEX treatment resulted in a significant increase in protein level of MTA3 compared to all experimental groups at $19 \mathrm{dg}(\mathrm{p}<0.01-p<0.001$; Fig. 4.b). With advanced gestation (at $21 \mathrm{dg})$, MTA3 protein level in the LZ showed significantly lower level of expression in all groups compared to their corresponding groups at $19 \mathrm{dg}(p<0.05-p<0.001$; Fig. 4.b) with no difference in the expression between groups.

In the BZ, MTA3 gene levels were lower in all the groups at $21 \mathrm{dg}$ compared to their corresponding groups at $19 \mathrm{dg}$, except DEX-treated group ( $<0.05-p<0.01$; Fig. 4.c). The protein expression of MTA3 in the BZ showed significant increase with P4 treatment compared C group $(p<0.05$; Fig. 4.d). However, with advanced gestation the level of MTA3 expression with P4 decreased compared to $19 \mathrm{dg}$ (p,0.05; Fig. 3.d) and the difference in the expression diminished between the groups.

\section{Discussion}


Dexamethasone effect on the extent of IUGR development depends greatly on the dose and the route of administration [36]. The regiment of DEX treatment in the present study was based on literature review in inducing moderate IUGR $[16,29]$. Dexamethasone in the present model induced a clear IUGR with $18 \%$ reduction in fetal body weight and $30 \%$ reduction in placental weight. Dexamethasone also induced a reduction in the detected level of maternal P4 as reported previously $[1,22]$.

The reduction in maternal serum P4 levels are normal towards the end of pregnancy due to apoptosis of the basal zone [17]. However, DEX treatment exaggerates the apoptotic process in this zone [17]. The basal zone is responsible for hormonal production and increased apoptosis in this zone is believed to lower the levels of placental lactogens secretion that stimulate ovarian P4 production [37]. Hence, leading to lower levels of maternal P4 with DEX treatment as detected in our study.

The regiment of P4 treatment in the present study was modified from previous studies on the effect of P4 on pregnancy outcomes [30,38]. Progesterone administered did not cause a significant increase in maternal P4 levels compared to $\mathrm{C}$ group possibly due to increased excretion of P4 metabolite that was seen when P4 levels increases [39]. However, at 19 dg, maternal P4 levels increased significantly when P4 was co-treated with DEX, possibly due to the lack of DEX inhibitory effect on placental endocrine function after a short DEX exposure (15-18 dg). Another possibility is the effect of DEX on reducing the activity of P4 catabolic enzymes at this gestational age [40].

The reduction in fetal and placental weights with DEX treatment were associated with lower levels of P4 detected in maternal serum. P4 co-treatment with DEX prevented the reduction in fetal weight. This could be explained by maintaining the weight of placenta and preserving placental function seen with P4 treatment. Placental efficiency, which indicates the placental capability in providing the fetus, was improved with DEX treatment. This may imply that, as a compensatory mechanism, the placenta is preserving fetal weight at the expense of its own growth. The efficiency improved further when DEX was cotreated with P4.

Metastasis tumor antigens are well known for their involvement in the pathway of cell proliferation and apoptosis. MTA1, 2 and 3 have been detected in human [27] and rat placentas [16, 33]. In the present study, MTA2 was not evaluated because it lacked to prove its significance in placental development and IUGR in DEX-induced IUGR model [16]. MTA1 is known for its role in proliferation and DNA damage repair through upregulating beta-catenin and cyclin D1 [25-27]. Placental growth ceases by $19 \mathrm{dg}$, indicated by no change in placental weight between 19 and $21 \mathrm{dg}$ seen in the present study and previous studies [16, 31]. Furthermore, placental apoptosis is known to take place towards the end of pregnancy [17, 41]. This is associated to lower level of MTA1 expression detected in the present study in both placental zones by $21 \mathrm{dg}$ compared to $19 \mathrm{dg}$. The effect of DEX on decreased MTA1 expression was seen in placental basal zone at $19 \mathrm{dg}$ only. Since placental levels of beta-catenin was found to be reduced in DEX-induced IUGR model [16], it is believed that DEX inhibits the effect of MTA1 by decreasing the expression of betacatenin and Wnt pathway leading to decreased proliferation seen in IUGR placentas. The basal zone is the zone responsible for hormonal production, any reduction in the size of this zone, as seen with DEX 
treatment in the present study, would directly affect hormonal production noticed as reduction in P4 level and fetal development.

On the other hand, MTA3 is known for its apoptotic effect by inhibiting beta-catenin and blunting Wnt pathway $[27,28]$. Gene and protein expressions of MTA3 did not follow the same patterns in the placental labyrinth zone, possibly due to post-translational modifications. The DEX-treated group at $19 \mathrm{dg}$ showed significant increase in MTA3 protein expression in the LZ. This increase in MTA3 expression and the reduction in the downstream beta-catenin seen in a previous study in the same zone [16] is believed to be one of the reasons behind decreasing cell proliferation and increasing apoptosis of placental LZ seen with DEX treatment. The LZ is the part of the placenta responsible for nutrient delivery to the fetus. Reduction in fetal body weight seen with DEX treatment could be a direct effect of a reduction in the exchange interface between the mother and the fetus.

\section{Conclusion}

DEX treatment induced clear IUGR indicated by reduction in fetal and placental growth. The restriction in pregnancy outcomes seen with DEX treatment is believed to be through decreasing the expression of placental proliferative antigen MTA1 and increasing the expression of MTA3 that supresses proliferation and induces apoptosis. P4 treatment prevented the increase in MTA3 levels detected with DEX treatment. Co-administration of P4 with DEX proved to prevent the reduction in fetal body weight and placental weight seen with DEX treatment through modulating the expression of MTA1 and MTA3. However, the downstream signalling pathways underlying P4 modulatory effect need to be further explored.

\section{Declarations}

\section{Acknowlegment}

We would like to acknowledge the Research Sector, Kuwait University (Grant no. MY01/17) for funding this project.

\section{Funding}

This work was funded by the Research Sector, Kuwait University (Grant no. MY01/17).

\section{Conflict of interest}

The authors have no relevant financial or non-financial interests to disclose.

\section{Availability of data and materials}

All data generated or analysed during this study are included in this published article.

\section{Code availability}


Not applicable.

\section{Authors' contributions}

Maie Al-Bader participated in grant writing, statistical analysis and revising this manuscript. Mariam AlAwadhi participated in grant writing, experiment conduction, data collection, statistical analysis and writing of this manuscript. Farah Al-Shammari and Fatemah Mulla Ali participated in experiment conduction, data collection and statistical analysis. Rama Almatar and Ayat Al-Duwaikhi participated in experiment conduction and data collection.

\section{Ethics approval and consent to participate}

Experimental animals were treated according to the National Institute of Health $(\mathrm{NIH})$ and Animal Research: Reporting In Vivo Experiment (ARRIVE) guidelines and approved by Kuwait University Health Sciences Center Animal Research Ethics Committee.

\section{Consent to participate}

Not applicable

\section{Consent for publication}

Not applicable

\section{References}

1. Kaneoka T, Shimizu H, Matsuoka I, Taguchi S, Shirakawa K (1982) [Prenatal diagnosis and treatments of intrauterine growth retardation (author's transl)]. Nihon Sanka Fujinka Gakkai zasshi 34(2):233-242

2. Wadhwa BS, Tempe L (2013) A, Role of dydrogesterone in the treatment of idiopathic IUGR. International Journal of Reproduction Contraception Obstetrics Gynecology 2(2):157-160

3. Newbern D, Freemark M, Placental hormones and the control of maternal metabolism and fetal growth, Current opinion in endocrinology, diabetes, and obesity 18(6) (2011) $409-16$

4. Conneely OM, Mulac-Jericevic B, DeMayo F, Lydon JP (2002) B.W. O'Malley, Reproductive functions of progesterone receptors. Recent Prog Horm Res 57:339-355

5. Arruvito L, Giulianelli S, Flores AC, Paladino N, Barboza M, Lanari C, Fainboim L (2008) NK cells expressing a progesterone receptor are susceptible to progesterone-induced apoptosis. J Immunol 180(8):5746-5753

6. Fukuyama A, Tanaka K, Kakizaki I, Kasai K, Chiba M, Nakamura T, Mizunuma H (2012) Antiinflammatory effect of proteoglycan and progesterone on human uterine cervical fibroblasts. Life Sci 90(13-14):484-488 
7. Rider V, Talbott A, Bhusri A, Krumsick Z, Foster S, Wormington J, Kimler BF (2016) WINGLESS (WNT) signaling is a progesterone target for rat uterine stromal cell proliferation. J Endocrinol 229(2):197207

8. Rider V, Isuzugawa K, Twarog M, Jones S, Cameron B, Imakawa K, Fang J (2006) Progesterone initiates Wnt-beta-catenin signaling but estradiol is required for nuclear activation and synchronous proliferation of rat uterine stromal cells. J Endocrinol 191(3):537-548

9. Kim M, Park HJ, Seol JW, Jang JY, Cho YS, Kim KR, Choi Y, Lydon JP, Demayo FJ, Shibuya M, Ferrara N, Sung HK, Nagy A, Alitalo K, Koh GY (2013) VEGF-A regulated by progesterone governs uterine angiogenesis and vascular remodelling during pregnancy. EMBO Mol Med 5(9):1415-1430

10. Molinari C, Battaglia A, Grossini E, Mary DA, Surico N, Vacca G (2001) Effect of progesterone on peripheral blood flow in prepubertal female anesthetized pigs. J Vasc Res 38(6):569-577

11. Kowalik MK, Rekawiecki R, Kotwica J (2013) The putative roles of nuclear and membrane-bound progesterone receptors in the female reproductive tract. Reprod Biol 13(4):279-289

12. Pecci A, Scholz A, Pelster D, Beato M (1997) Progestins prevent apoptosis in a rat endometrial cell line and increase the ratio of bcl-XL to bcl-XS. J Biol Chem 272(18):11791-11798

13. Wang Y, Hanifi-Moghaddam P, Hanekamp EE, Kloosterboer HJ, Franken P, Veldscholte J, van Doorn HC, Ewing PC, Kim JJ, Grootegoed JA, Burger CW, Fodde R, Blok LJ (2009) Progesterone inhibition of Wnt/beta-catenin signaling in normal endometrium and endometrial cancer. Clin Cancer Res 15(18):5784-5793

14. Burton GJ, Woods AW, Jauniaux E, Kingdom JC (2009) Rheological and physiological consequences of conversion of the maternal spiral arteries for uteroplacental blood flow during human pregnancy. Placenta 30(6):473-482

15. Al-Bader MD, Jasem SA, Kilarkaje N (2016) Carbenoxolone exposure during late gestation in rats alters placental expressions of p53 and estrogen receptors. Eur J Pharmacol 791:675-685

16. Alqaryyan M, Kilarkaje N, Mouihate A, Al-Bader MD (2017) Dexamethasone-Induced Intrauterine Growth Restriction Is Associated With Altered Expressions of Metastasis Tumor Antigens and Cell Cycle Control Proteins in Rat Placentas. Reprod Sci 24(8):1164-1175

17. Waddell BJ, Hisheh S, Dharmarajan AM, Burton PJ (2000) Apoptosis in rat placenta is zonedependent and stimulated by glucocorticoids. Biol Reprod 63(6):1913-1917

18. Fonseca BM, Correia-da-Silva G, Teixeira NA (2012) The rat as an animal model for fetoplacental development: a reappraisal of the post-implantation period. Reprod Biol 12(2):97-118

19. Romero R, Nicolaides K, Conde-Agudelo A, Tabor A, O'Brien JM, Cetingoz E, Da Fonseca E, Creasy GW, Klein K, Rode L, Soma-Pillay P, Fusey S, Cam C, Alfirevic Z, Hassan SS, Vaginal progesterone in women with an asymptomatic sonographic short cervix in the midtrimester decreases preterm delivery and neonatal morbidity: a systematic review and metaanalysis of individual patient data, American journal of obstetrics and gynecology 206(2) (2012) 124 e1-19

20. Hassan SS, Romero R, Vidyadhari D, Fusey S, Baxter JK, Khandelwal M, Vijayaraghavan J, Trivedi Y, Soma-Pillay P, Sambarey P, Dayal A, Potapov V, O'Brien J, Astakhov V, Yuzko O, Kinzler W, Dattel B, 
Sehdev H, Mazheika L, Manchulenko D, Gervasi MT, Sullivan L, Conde-Agudelo A, Phillips JA, Creasy $\mathrm{GW}$, Trial P, Vaginal progesterone reduces the rate of preterm birth in women with a sonographic short cervix: a multicenter, randomized, double-blind, placebo-controlled trial, Ultrasound in obstetrics \& gynecology: the official journal of the International Society of Ultrasound in Obstetrics and Gynecology 38(1) (2011) 18-31

21. Kumar A, Begum N, Prasad S, Aggarwal S, Sharma S, Oral dydrogesterone treatment during early pregnancy to prevent recurrent pregnancy loss and its role in modulation of cytokine production: a double-blind, randomized, parallel, placebo-controlled trial, Fertil Steril 102(5) (2014) 1357-1363 e3

22. Wadhwa L, Batra S, Tempe A (2013) Role of dydrogesterone in the treatment of idiopathic IUGR. International Journal of Reproduction Contraception Obstetrics Gynecology 2(2):157

23. Liu J, Matsuo H, Laoag-Fernandez JB, Xu Q, Maruo T (2007) The effects of progesterone on apoptosis in the human trophoblast-derived HTR-8/SV neo cells. Molecular human reproduction 13(12):869-874

24. Kumar R, Wang RA, Bagheri-Yarmand R (2003) Emerging roles of MTA family members in human cancers. Semin Oncol 30(5 Suppl 16):30-37

25. Manavathi B, Singh K, Kumar R (2007) MTA family of coregulators in nuclear receptor biology and pathology. Nucl Recept Signal 5:e010

26. Manavathi B, Kumar R (2007) Metastasis tumor antigens, an emerging family of multifaceted master coregulators. J Biol Chem 282(3):1529-1533

27. Bruning A, Makovitzky J, Gingelmaier A, Friese K, Mylonas I (2009) The metastasis-associated genes MTA1 and MTA3 are abundantly expressed in human placenta and chorionic carcinoma cells. Histochem Cell Biol 132(1):33-38

28. Zhang H, Singh RR, Talukder AH, Kumar R (2006) Metastatic tumor antigen 3 is a direct corepressor of the Wnt4 pathway. Genes Dev 20(21):2943-2948

29. Shoener JA, Baig R, Page KC (2006) Prenatal exposure to dexamethasone alters hippocampal drive on hypothalamic-pituitary-adrenal axis activity in adult male rats. Am J Physiol Regul Integr Comp Physiol 290(5):R1366-R1373

30. Hashimoto H, Eto T, Endo K, Itai G, Kamisako T, Suemizu H, Ito M (2010) Comparative study of doses of exogenous progesterone administration needed to delay parturition in $\mathrm{Jcl}: \mathrm{MCH}(\mathrm{ICR})$ mice, Experimental animals /. Japanese Association for Laboratory Animal Science 59(4):521-524

31. Furukawa S, Hayashi S, Usuda K, Abe M, Hagio S, Ogawa I (2011) Toxicological pathology in the rat placenta. Journal of toxicologic pathology 24(2):95-111

32. Romero A, Villamayor F, Grau MT, Sacristan A, Ortiz JA (1992) Relationship between fetal weight and litter size in rats: application to reproductive toxicology studies. Reprod Toxicol 6(5):453-456

33. Al-Bader MD, Kilarkaje N, El-Farra A, Al-Abdallah AA (2015) Expression and subcellular localization of metastasis-associated protein 1, its short form, and estrogen receptors in rat placenta. Reprod Sci 22(4):484-494 
34. Al-Bader M, Kilarkaje N (2015) Effects of bleomycin, etoposide and cisplatin treatment on Leydig cell structure and transcription of steroidogenic enzymes in rat testis. Eur J Pharmacol 747:150-159

35. Livak KJ, Schmittgen TD (2001) Analysis of relative gene expression data using real-time quantitative PCR and the 2(-Delta Delta C(T)). Method Methods 25(4):402-408

36. Vaughan OR, Sferruzzi-Perri AN, Coan PM, Fowden AL (2013) Adaptations in placental phenotype depend on route and timing of maternal dexamethasone administration in mice. Biol Reprod 89(4):80

37. Ain R, Canham LN, Soares MJ (2005) Dexamethasone-induced intrauterine growth restriction impacts the placental prolactin family, insulin-like growth factor-II and the Akt signaling pathway. J Endocrinol 185(2):253-263

38. Norwitz ER, Caughey AB (2011) Progesterone supplementation and the prevention of preterm birth. Rev Obstet Gynecol 4(2):60-72

39. Blackwell LF, Cooke DG, Brown S (2018) The Use of Estrone-3-Glucuronide and Pregnanediol-3Glucuronide Excretion Rates to Navigate the Continuum of Ovarian Activity. Front Public Health 6:153

40. Agular BM, Vinggaard AM, Vind C (1992) Regulation by dexamethasone of the 3 beta-hydroxysteroid dehydrogenase activity in adult rat Leydig cells. J Steroid Biochem Mol Biol 43(6):565-571

41. Waddell BJ, Benediktsson R, Brown RW, Seckl JR (1998) Tissue-specific messenger ribonucleic acid expression of 11beta-hydroxysteroid dehydrogenase types 1 and 2 and the glucocorticoid receptor within rat placenta suggests exquisite local control of glucocorticoid action. Endocrinology 139(4):1517-1523

\section{Tables}

Due to technical limitations, table 2 is only available as a download in the Supplemental Files section.

\section{Figures}




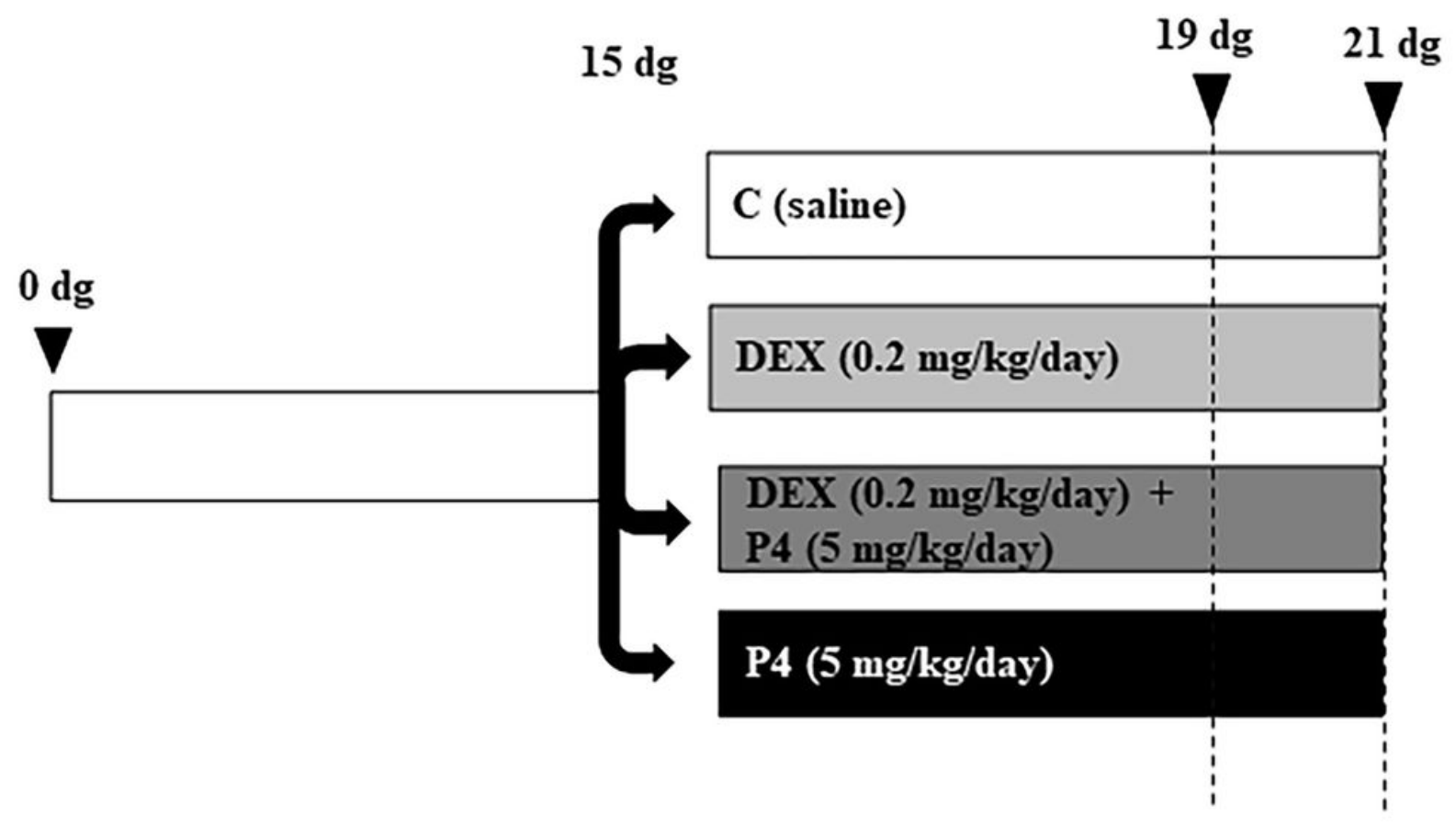

Figure 1

Experimental design. The day at which sperms were detected in vaginal smear was considered as $0 \mathrm{dg}$. Pregnant rats were caged separately. At $15 \mathrm{dg}$ rats were allocated to 4 different experimental groups based on daily i.p. Injections. Animals in $\mathrm{C}$ group were injected with saline, animals in DEX group were injected with DEX $(0.2 \mathrm{mg} / \mathrm{Kg} /$ day $)$, animals in DEX + P4 group were injected with DEX $(0.2 \mathrm{mg} / \mathrm{Kg} / \mathrm{day})$ and P4 (5 mg/kg/day), and animals in P4 group were injected with P4 only ( $5 \mathrm{mg} / \mathrm{Kg} /$ day). Animals were sacrificed either at 19 or $21 \mathrm{dg}$. No injections were given at the day of dissection
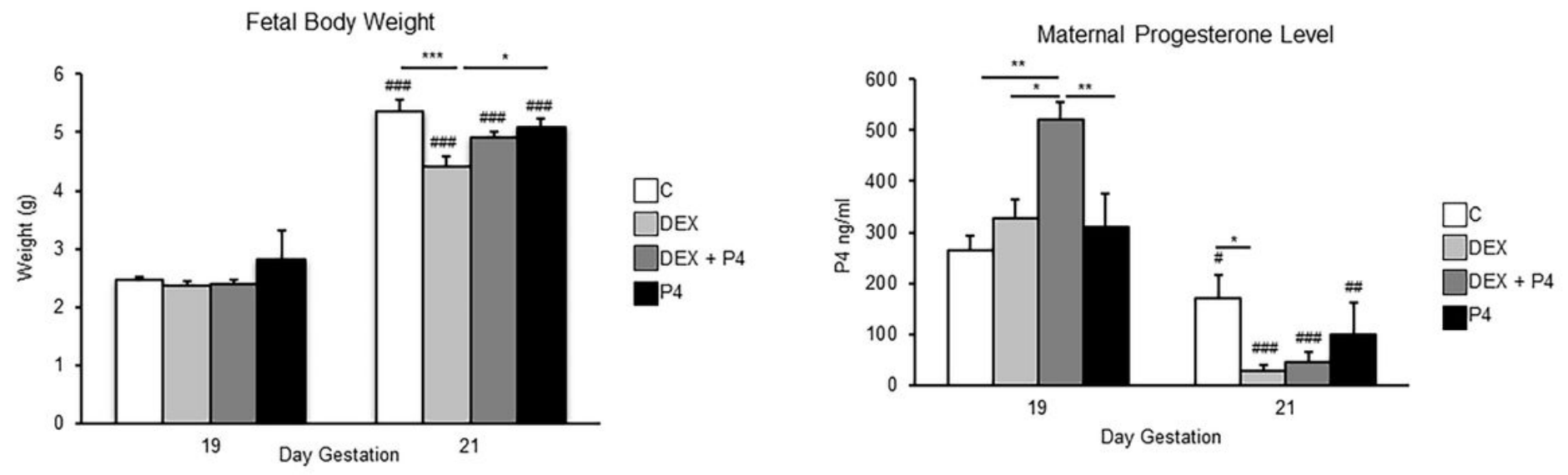

Figure 2 
(a) Average fetal body weights at 19 and $21 \mathrm{dg}$; the fetal body weight was significantly decreased with DEX treatment at $21 \mathrm{dg}$ compared to $\mathrm{C}$ group. (b) Average maternal progesterone (P4) at $19 \mathrm{dg}$ and $21 \mathrm{dg}$; maternal P4 levels were higher in the DEX + P4 group compared to all other groups. At $21 \mathrm{dg}$ maternal P4 level decreased in all groups at compare to the same group at $19 \mathrm{dg}$. P4 level decreased further with DEX

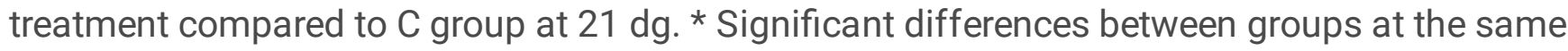
gestational age ( $\left.{ }^{*} p<0.05,{ }^{*} \mathrm{p}<0.01 * * *, p<0.001\right)$; \# Significant differences between $19 \mathrm{dg}$ and the corresponding group on $21 \mathrm{dg}(\# p<0.05$, \#\#p < 0.01\#\#\#, $p<0.001)$. Control (C), dexamethasone (DEX), dexamethasone and progesterone (DEX $+\mathrm{P} 4)$, and progesterone (P4) treated groups. Data are represented as mean \pm SEM $(n=6)$
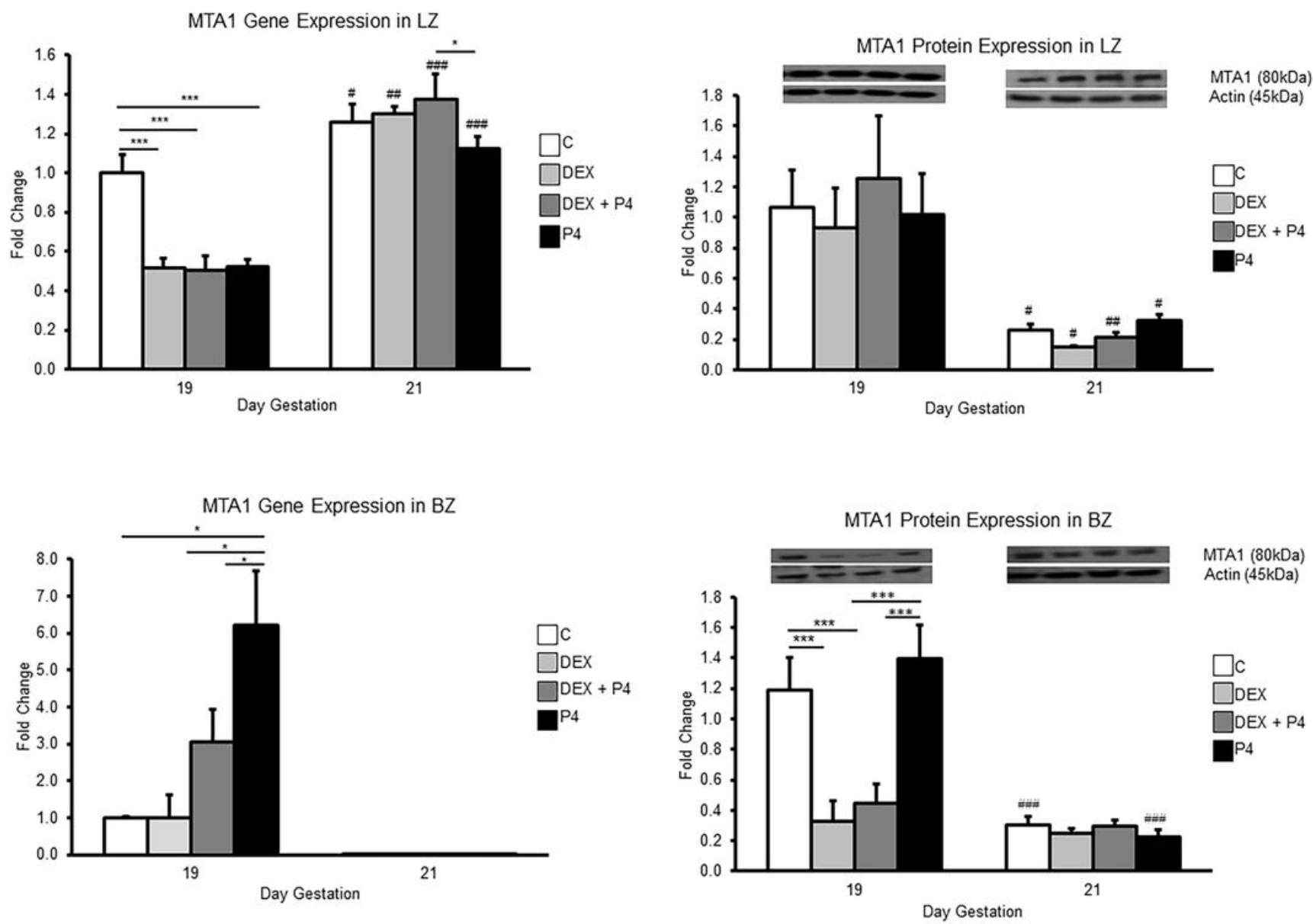

Figure 3

(a) MTA1 gene expression and (b) protein expressions in the LZ at 19 and $21 \mathrm{dg}$; MTA1 gene expression in $\mathrm{C}$ groups was significantly higher than all other groups at $19 \mathrm{dg}$. The gene expression increased significantly with gestation from 19 to $21 \mathrm{dg}$ in all the experimental groups. Protein expression of MTA1 decreased significantly in all groups at $21 \mathrm{dg}$ compared to their corresponding groups at $19 \mathrm{dg}$. (c) MTA1 gene expression and (d) protein expressions in the BZ at 19 and $21 \mathrm{dg}$; P4 treatment resulted in significant increase in gene expression compared to all other groups at $19 \mathrm{dg}$. Protein expression of MTA1 at $19 \mathrm{dg}$ decreased significantly with DEX treatment compared to $\mathrm{C}$ and P4 groups. The difference 
in protein expression between groups disappeared by $21 \mathrm{dg}$. ${ }^{*}$ Significant differences between groups at the same gestational age $\left({ }^{\star} \mathrm{p}<0.05,{ }^{* \star} \mathrm{p}<0.001\right)$; \# significant differences between $19 \mathrm{dg}$ and the corresponding group on $21 \mathrm{dg}(\# p<0.05, \# \# p<0.01, \# \# \# p<0.001)$. Control (C) dexamethasone (DEX), dexamethasone and progesterone (DEX + P4), and progesterone (P4) treated groups. Data are represented as mean \pm SEM $(n=6)$
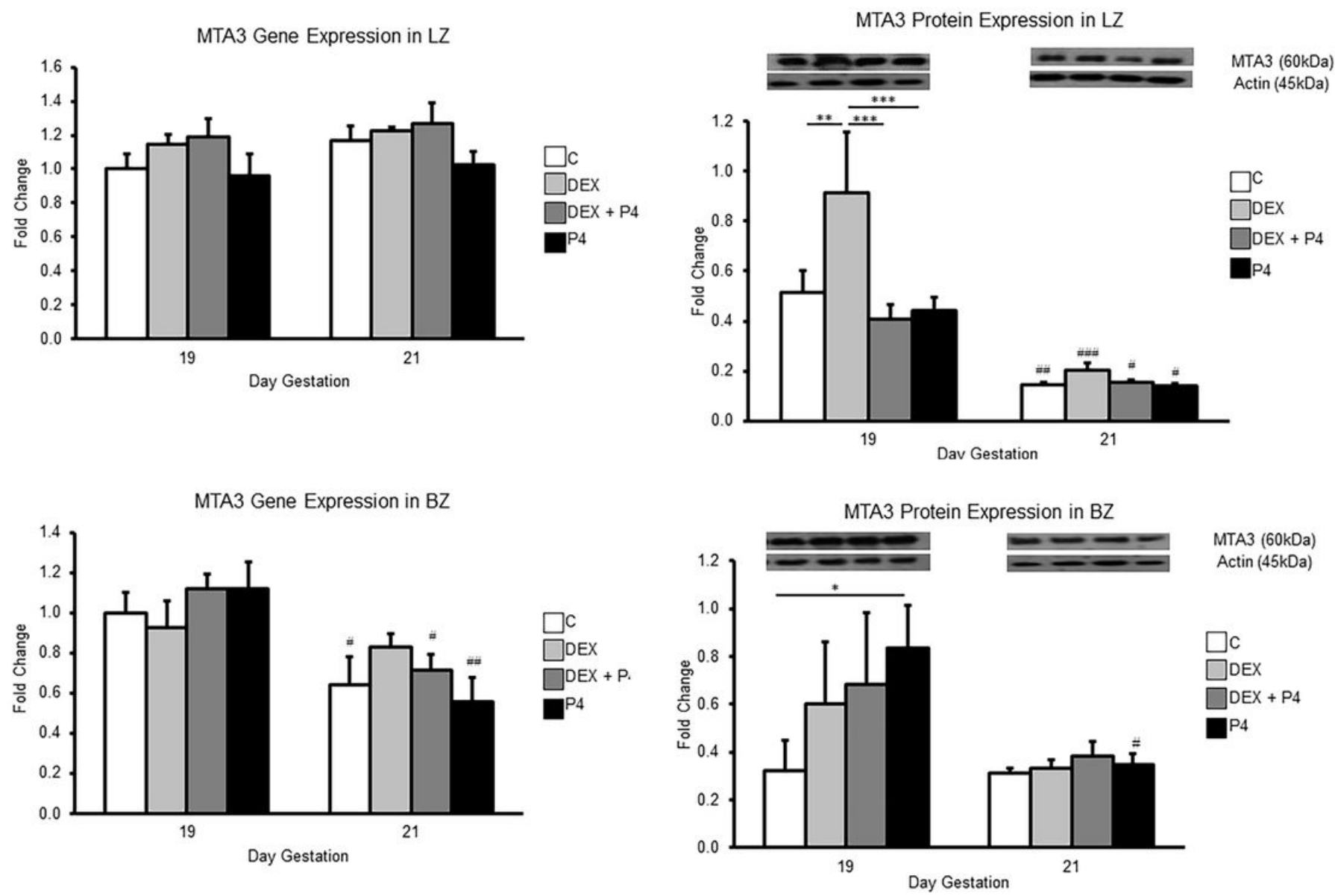

\section{Figure 4}

(a) MTA3 gene expression and (b) protein expression in the LZ at 19 and $21 \mathrm{dg}$; MTA 3 gene levels did not show any significant difference between groups neither between different gestational ages. MTA3 protein expression increased significantly with DEX treatment at $19 \mathrm{dg}$. At $21 \mathrm{dg}$ the level of MTA3 protein expression decreased in all experimental groups compared to their corresponding groups at $19 \mathrm{dg}$. (c) MTA3 gene expression and (b) protein expression in the BZ at 19 and 21 dg; MTA3 gene expression decreased significantly in all experimental groups between 19 and $21 \mathrm{dg}$, except DEX-treated group. Protein level of MTA3 increased significantly with P4 treatment at $19 \mathrm{dg}$. A finding that disappeared by 21 dg due to significant reduction in protein level in P4 at this gestational age compared to $19 \mathrm{dg}$. Significant differences between groups at the same gestational age $\left({ }^{\star} p<0.05,{ }^{*} p<0.01,{ }^{\star \star \star} p<0.001\right)$; \# Significant differences between $19 \mathrm{dg}$ and the corresponding group on $21 \mathrm{dg}(\# p<0.05$, \#\#p $<0.01$, $\# \# \# p<0.001)$. Control (C), dexamethasone (DEX), dexamethasone and progesterone (DEX + P4), and progesterone (P4) treated groups. Data are represented as mean \pm SEM $(n=6)$ 


\section{Supplementary Files}

This is a list of supplementary files associated with this preprint. Click to download.

- Table2.tif

- SupFig5.tif

- SuppTable1.tif 